\title{
Rheumatoid arthritis-associated uveitis treated with adalimumab
}

\section{Zapalenie błony naczyniowej powiązane z reumatoidalnym zapaleniem stawów leczone adalimumabem}

\author{
Elżhieta Kalaczyńska, Ewa Bilińska, Marta Owidzka \\ Department of Ophthalmology, Medical University of Lodz, Poland \\ Head: Professor Wojciech Omulecki, MD, PhD
}

\begin{abstract}
Ahstract: $\quad$ Uveitis is an inflammatory ocular disorder of various aetiology affecting the middle vascular layer of the eye. The condition mainly affects relatively young patients and if untreated, it can lead to significant complications, including blindness. Hence, it is of a critical importance to prevent inflammation and vision loss in eyes with uveitis.

Here, we report a case of a 36-year-old male with a history of rheumatoid arthritis, who was first diagnosed with anterior uveitis, and subsequently presented with macular oedema and epiretinal membranes. However, conventional treatment with a steroid was not sufficient to control the inflammation and was associated with elevated intraocular pressure as a side effect. Eventually, the patient was treated with adalimumab, which effectively prevented disease progression and resolved his rheumatoid symptoms.

Key words: $\quad$ uveitis, adalimumab, rheumatoid arthritis, macular oedema, epiretinal membrane.

Ahstrakt: $\quad$ Zapalenie błony naczyniowej to schorzenie oka o różnorodnej etiologii. Stan ten dotyka relatywnie młodych pacjentów, jeśli pozostaje nieleczony może prowadzić do znaczących komplikacji, w tym ślepoty. Stąd, zapobieganie rozwojowi zapalenia oraz utraty wzroku jest tak istotne.

Przedstawiono przypadek 36-letniego mężczyzny. U pacjenta z wywiadem reumatoidalnego zapalenia stawów zdiagnozowano początkowo zapalenie przedniego odcinka błony naczyniowej, następnie obrzęk plamki oraz błonę nasiatkówkową. Jednakże, konwencjonalna terapia steroidami nie była wystarczająca do uzyskania kontroli choroby oraz była związana z wystąpieniem działania niepożądanego w postaci wzrostu ciśnienia wewnątrzgałkowego. Ostatecznie zastosowano terapię przy użyciu adalimumabu. Terapia umożliwita zahamowanie progresji choroby oraz ustąpienie objawów reumatologicznych.

Stowa kluczowe: zapalenie błony naczyniowej, adalimumab, reumatoidalne zapalenie stawów, obrzęk plamki, błona nasiatkówkowa.

The authors declare no conflict of interest/ Autorzy zgłaszają brak konfliktu interesów w związku z publikowaną pracą
\end{abstract}

\section{Introduction}

The term uveitis denotes an inflammation of the uvea which comprises the iris, ciliary body and choroid; however, it also involves the inflammation of adjacent intraocular structures. It can occur both as a stand-alone condition and secondary to other disorders. It is of a critical importance to prevent inflammation and vision loss in eyes with uveitis, as the condition has been identified as a major cause of blindness (1). Established therapy strategy recognises topical steroids as the first line, however chronic or more severe cases demand use of oral steroids or immunosuppressive drugs. For a significant number of patients, disease severity, adverse effects and need for high drug doses facilitate a decision for alternative management $(2,4)$. The most recent addition to the available armamentarium consists of anti-TNF agents.

\section{Case report}

A 36-year-old male with a history of rheumatoid arthritis was referred to the hospital outpatient clinic with reduced visual acuity in both eyes in January 2013. His uncorrected visual acuity was 0.5 in both eyes, and ophthalmic examination reve- aled anterior uveitis and macular oedema. The patient was treated with topical steroids, followed by acetazolamide. However, his vision deteriorated despite treatment. After the intravitreal steroid (triamcinolone) injection administered to the right eye in June 2014, he reported subjective improvement, nevertheless vision acuity loss and macular oedema persisted. In November 2014, funduscopy and OCT (Fig. 1) revealed epiretinal membranes present bilaterally, more pronounced in the left eye. However, active inflammation precluded surgical treatment, which was postponed until achieving symptom control. In January 2015, the patient was diagnosed with recurrent anterior uveitis. He was administered topical NSAIDs, corticosteroids, antibiotics and tropicamide, as well as gentamycin + dexamethasone in subconjunctival injections. In February, another two triamcinolone injections were administered to the left eye. Due to the spread of inflammation posteriorly and the exacerbation of uveitis, the patient had to be hospitalized. He was treated with methylprednisolone. The response included a short-term remission followed by subsequent flare-up - a sequence, which repeated several times. In April 2017, triamcinolone was injected for the third time due to persistent macular oedema and in June 2017, 

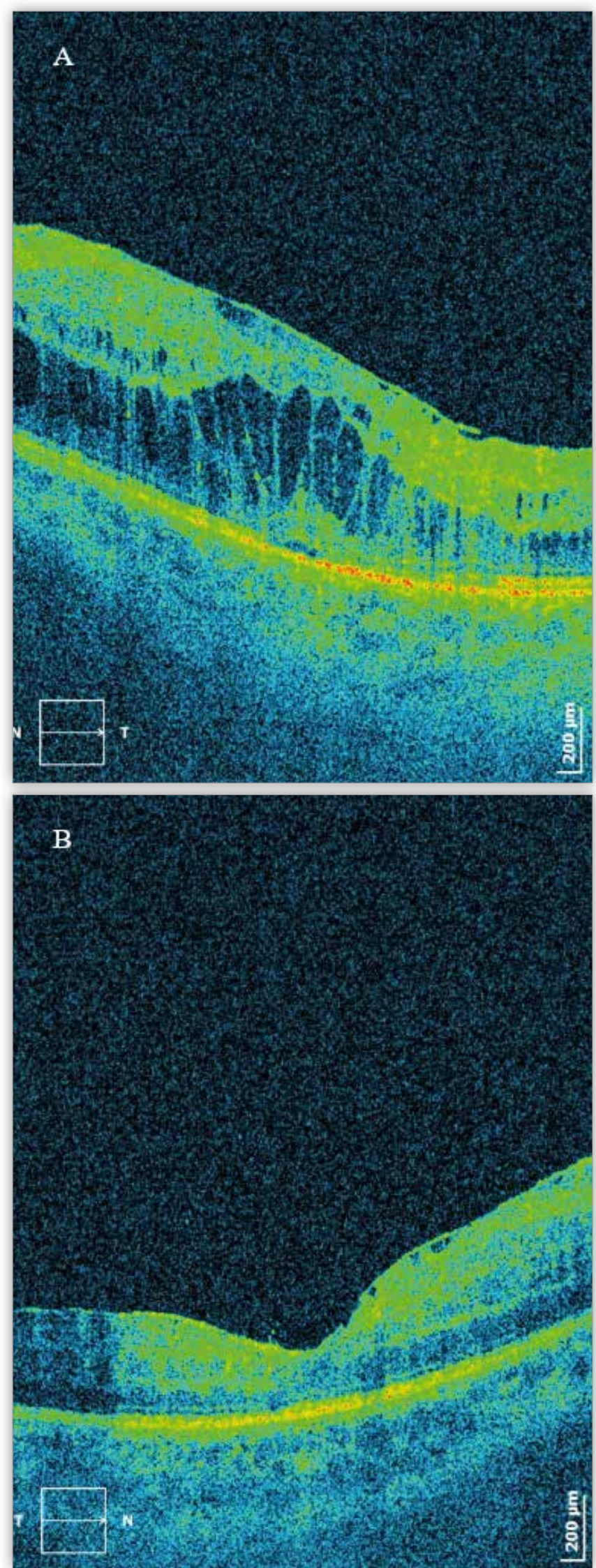

Fig. 1. OCT scan showing cystoid macular oedema and the ERM of the left eye (A) and the right eye (B) in November 2014.

Ryc. 1. Badanie OCT ukazujące torbielowaty obrzęk plamki i błonę nasiatkówkową w oku lewym (A) oraz w oku prawym (B) w listopadzie 2014. the patient presented with elevated intraocular pressure (IOP $\mathrm{RE}=18 \mathrm{mmHg}, \mathrm{IOP} \mathrm{LE}=22 \mathrm{mmHg}$ ), which was managed with timolol. On indirect ophthalmoscopy, vitreal opacities and vasculitis were found in the left eye, with no evidence of macular oedema. The patient eligibility for biologic treatment was assessed. He underwent pars plana vitrectomy (PPV) for epiretinal membrane removal in November 2017. The postoperative best corrected visual acuity (BCVA) was 6/15 and 6/18 in right and left eye, respectively. Uveitis recurred again in February 2018. He responded to treatment, but had elevated IOP in his left eye (IOP RE $=10 \mathrm{mmHg}$; IOP LE $=22 \mathrm{mmHg}$ ). As the patient met all eligibility criteria to take part in a therapeutic drug programme, he was started on biological treatment with Adalimumab. The administration schedule and dosage (80 mg loading dose; $40 \mathrm{mg}$ maintenance dose) were adapted from manufacturer's recommendations. This new therapy resulted in a considerably positive outcome (Fig. 2). Although the initial improvement did not fully restore his baseline visual acuity, it slowed disease progression and helped to achieve stable BCVA (BCVA RE = $6 / 12$; BCVA LE $=6 / 19$ ). The greatest improvement included symptomatic resolution of rheumatoid arthritis and associated joint pain. Furthermore, biological therapy enabled de-escalation of DMARD treatment from the initial regimen including methotrexate $15 \mathrm{mg} /$ week and prednisolone $5 \mathrm{mg} /$ day to daily prednisolone at unchanged dose with complete methotrexate discontinuation.

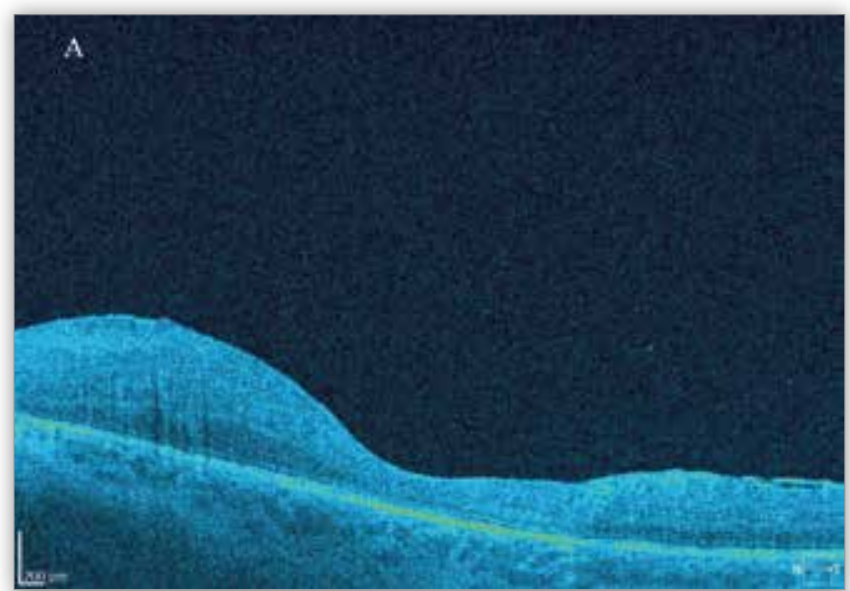

B

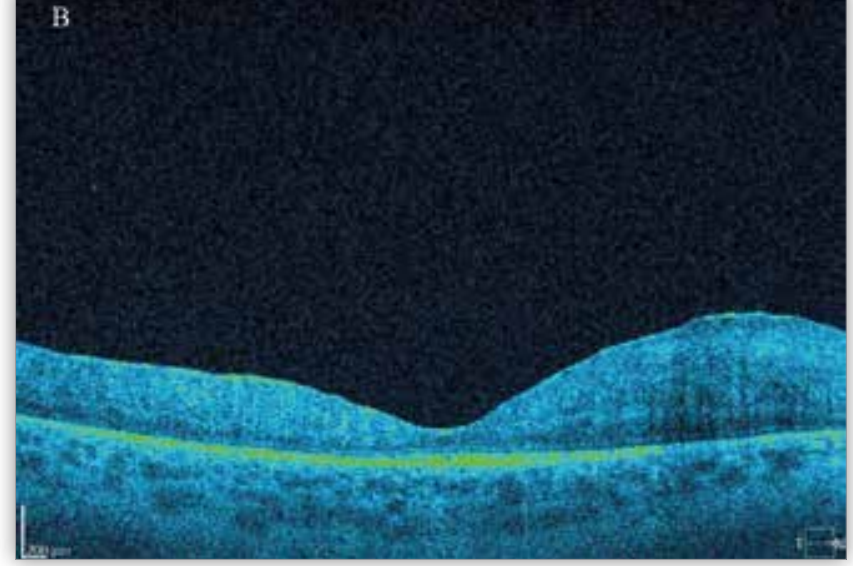

Fig. 2. OCT scan of the left eye $(A)$ and the right eye $(B)$ during treatment with adalimumab in October 2018.

Ryc. 2. Badanie OCT oka lewego (A) oraz oka prawego (B) w trakcie leczenia Adalimumabem w październiku 2018. 


\section{Discussion}

Biological agents offer high efficacy and low adverse effect rates, which can make them them more beneficial than steroids. They are indicated in patients not responding or not tolerating conventional immunosuppressive therapy. Furthermore, they enable clinicians to treat concomitant ophthalmic and systemic inflammation with just one drug. Although adalimumab has been used in treatment of uveitis since 2006, it still remains the last resort treatment and lack of sufficient evidence limits the possibility of using it at earlier stages of the disease. Adalimumab is a recombinant human IgG1 monoclonal antibody targeting the TNF- $\alpha$. TNF- $\alpha$ is believed to play a crucial role in pathogenesis of non-infectious uveitis, as it both induces and maintains the inflammation in autoimmune response $(2,3,5)$. Whilst adalimumab has well documented efficacy in reducing signs and symptoms of joint involvement in rheumatoid conditions, it also has an effect on ocular involvement, with an additional advantage of subcutaneous dosing (SO) over other available biological agents which require intravenous injections $(2,3,6,7)$. The meta-analysis for adalimumab efficacy revealed that patients treated with adalimumab had a more favourable outcome proving effective in around $80 \%$ of cases $(4,5,8)$. Adalimumab was not associated with serious adverse effects and the most common adverse effects included local injection site reactions. It was stated that adalimumab is less likely to generate allergic response, as the molecule is more humanized compared to infliximab. Accordingly, patients with hypersensitivity to infliximab were reported to have achieved remission after switching to adalimumab $(2,9)$. However, the comparison of adalimumab efficacy between treatment-naiive patients and those previously treated with other anti-TNF $\alpha$ agents is unclear and various outcomes have been reported $(8,9)$. The VISUAL study demonstrated the ability of adalimumab to reduce the risk of recurrent uveitis and vision loss in patients with both active (VISUAL I) and inactive disease (VISUAL II). In both mentioned studies, adalimumab offered significantly better improvement than placebo with fairly comparable risk levels, only slightly higher in adalimumab group (2). The observed adverse effects included susceptibility to infections (reactivation of tuberculosis, histoplasmosis, hepatitis $B$, and fungal infection), hypersensitivity reactions, demyelinating disease, lupus-like syndrome, malignancy, thromboembolic events, and congestive heart failure $(3,7)$. Adalimumab is considered a class $B$ drug during pregnancy as there is no sufficient data regarding its use in pregnancy (10). According to supplemental VISUAL III and other studies, adalimumab supressed inflammation and reduced the need for steroids and immunosuppressants $(6,9)$. However, some patients with non-infectious uveitis do not respond to treatment, present with hypersensitivity or develop resistance over time, possibly due to the formation of anti-drug antibodies $(3,7)$. If none of the treatment goals have been achieved, the diagnosis might need to be reviewed. Some experts point to surgical treatment as a possible alternative. However, interventions such as PPV or peripheral cryotherapy, have late complications and do not resoIve the underlying immune issues. Consequently, the gain from surgical procedure might be only temporary (11). Hamam et al. reported promising results of direct intravitreal Adalimumab administration, although no reliable conclusions can be drawn from this experimental treatment due to a limited number of subjects included in the study (5).

\section{Conclusions}

There is still a great need for further investigation in order to determine specific strategy and standards of the biological treatment. Biological response modifiers should be considered in patients who do not respond to or do not tolerate conventional immunosuppressive therapy. This strategy is particularly beneficial in patients with concomitant ophthalmic and systemic disease.

\section{References:}

1. Krishna U, Ajanaku D, Denniston AK, Gkika T: Uveitis: a sight-threatening disease which can impact all systems. Postgraduate Medical Journal. 2017;93:766-773.

2. Goto H, Zako M, Namba K, Hashida N, Kaburaki T, Miyazaki M, et al.: Adalimumab in Active and Inactive, Non-Infectious Uveitis: Global Results from the VISUAL I and VISUAL II Trials. Ocul Immunol Inflamm. 2018;00:1-11.

3. Jaffe GJ, Dick AD, Brézin AP, Nguyen QD, Thorne JE, Kestelyn $\mathrm{P}$, et al.: Adalimumab in Patients with Active Noninfectious Uveitis. N Engl J Med. 2016;375:932-943.

4. Mérida S, Palacios E, Navea A, Bosch-Morell F: New Immunosuppressive Therapies in Uveitis Treatment. Int. J. Mol. Sci. 2015;16:18778-18795.

5. Hamam RN, Barikian AW, Antonios RS, Abdulaal MR, Alameddine RM, El Mollayess G, et al.: Intravitreal Adalimumab in Active Noninfectious Uveitis: A Pilot Study. Ocul Immunol Inflamm. 2016;24:319-326.

6. Suhler EB, Adán A, Brézin AP, Fortin E, Goto H, Jaffe GJ, et al.: Safety and Efficacy of Adalimumab in Patients with Noninfectious Uveitis in an Ongoing Open-Label Study: VISUAL III. Ophthalmology. 2018;125:1075-1087.

7. Pasadhika S, Rosenbaum JT: Update on the use of systemic biologic agents in the treatment of noninfectious uveitis. Biologics. 2014;8:67-81.

8. Dobner BC, Max R, Becker MD, Heinz C, Veltrup I, Heiligenhaus $\mathrm{A}$, et al.: $A$ three-centre experience with adalimumab for the treatment of non-infectious uveitis. $\mathrm{Br} \mathrm{J}$ Ophthalmol. 2013;97:134-138.

9. Ming S, Xie K, He H, Li Y, Lei B: Efficacy and safety of adalimumab in the treatment of non-infectious uveitis: a meta-analysis and systematic review. Drug Des Devel Ther. 2018;12:2005-2016.

10. Bessette AP, Sharma S: Adalimumab for noninfectious uveitis. Ophthalmol Retina. 2017;1:179-180.

11. Dick AD, Rosenbaum JT, Al-Dhibi HA, Belfort R Jr, Brézin AP, Chee SP, et al.: Guidance on Noncorticosteroid Systemic Immunomodulatory Therapy in Noninfectious Uveitis: Fundamentals Of Care for UveitiS (FOCUS) Initiative. Ophthalmology. 2018;125:757-773.

The paper was originally received 04.02.2019 (KO-00197-2019)/ Praca wpłynęła do Redakcji 04.02.2019 (KO-00197-2019)

Accepted for publication 15.04.2019/

Zakwalifikowano do druku 15.04.2019.

Reprint requests to (Adres do korespondencji):

Elżbieta Kalaczyńska

Department of Ophthalmology, Medical University of Lodz

Medical University Barlicki Hospital No.1, Kopcinskiego str. 22, 90-153 Lodz, Poland

e-mail: ela.kalaczynska@gmail.com 